\title{
Delineation of sedimentary basin structure beneath the Banyumas Basin, Central Java, Indonesia, using ambient seismic noise tomography
}

\author{
Ahmad Setiawan ${ }^{1,2^{*}}$ (D) Zulfakriza Zulfakriza ${ }^{3,4}$, Andri Dian Nugraha, ${ }^{3,4}$, Shindy Rosalia ${ }^{3,4}$, Awali Priyono $^{3}$, \\ Sri Widiyantoro ${ }^{3,4,5}$, David P. Sahara ${ }^{3,4}$, Marjiyono Marjiyono², Januar H. Setiawan², Eko Budi Lelono², \\ Asep K. Permana ${ }^{2}$ and Hidayat Hidayat ${ }^{1,2}$
}

\begin{abstract}
Subsurface images of an area with a thick volcanic layer generally cannot be well-imaged with conventional seismic exploration (seismic reflection) due to seismic wave scattering. Another method is needed to obtain an accurate subsurface image in a thick volcanic layer area. In this study, we applied ambient noise tomography (ANT) to image the shear-wave velocity (Vs) structure in the Banyumas Basin, Central Java, Indonesia, which has relatively thick volcanic layers. We aimed to delineate the sediment deposits and the sedimentary thickness in this area through the utilization of ambient seismic noise. The application of cross-correlations from ambient seismic noise has been widely applied in numerous locations to obtain a greater understanding of subsurface structures. In this study, more than 1000 pairs of vertical component cross-correlations were used to estimate the Green's Function of the Rayleigh wave. The Neighbourhood Algorithm (NA) was utilized to invert the dispersion curves at 121 grid points which were used to obtain a vertical depth profile of 1DVs. The Vs map results show that the low Vs tend to trend in a northwest-southeast direction associated with two areas: the Majenang low, and the Citanduy low. The presence of low Vs values corresponds with Middle Miocene-Pliocene sedimentary rocks. Meanwhile, the high Vs values in this area might correspond with Oligocene-Early Miocene volcanic products and Eocene sediment. Our study was also able to reveal the thickness of sedimentary rocks in the Banyumas sedimentary basin, which is believed to have hydrocarbon potential.
\end{abstract}

Keywords: Banyumas sedimentary basin, Volcanic area, Hydrocarbon, Ambient noise tomography, Cross-correlation, Green's Function, Rayleigh wave, Shear wave

\section{Introduction}

Java Island is located in the Indonesian archipelago and has unique geological features due to its subducting plate zone. The existence of a recent volcanic arc on the island is a result of interactions between the Eurasian and

\footnotetext{
*Correspondence: ahmad.setiawan@esdm.go.id

${ }^{1}$ Graduate Program of Geophysical Engineering, Faculty of Mining and Petroleum Engineering, Institut Teknologi Bandung, Jalan Ganesa No.

10, Bandung 40132, Indonesia

Full list of author information is available at the end of the article
}

Indo-Australian Plates in the southern part of Java. The Indo-Australian Plate moves relatively north, perpendicular to Java Island since the Late Cretaceous era (Hall 2012), subducting beneath the Eurasian Plate with a convergence rate of $67 \mathrm{~mm}$ year $^{-1}$ (Simons et al. 2007). This tectonic activity has caused the development of faults and basins in the area, which are important for oil and gas plays.

Situmorang et al. (1976) suggested that the northward lateral compression force from the Indian oceanic plate and the southward lateral compression force from the 
Sundaland block present a wrench fault tectonism on Java Island, as first explained by Moody and Hill (1956). Due to these forces, pairs of strike-slip faults developed in opposite directions which meet in southern Central Java and caused the geological settings in Central Java to become more complex than those of West and East Java (Satyana 2007). These faults have also modified the petroleum geology in Central Java, which generally developed in the forearc and backarc basins, as is present on Sumatra Island and on other parts of Java Island (Satyana 2007).

Our study area is Banyumas Basin, which is one of the inter-mountainous sedimentary basins located in the south of Central Java (Fig. 1). Oil and gas seepage can be found in several locations in the Banyumas Basin, which indicate an active petroleum system (Satyana 2007). The status of this area is still in the exploration stage; as a result, many researchers from government institutes and companies are attracted to commence research in this area, especially regarding the petroleum geology. Previous studies regarding the petroleum system in Banyumas Basin have been widely discussed; e.g., see (Noeradi et al. 2006; Subroto et al. 2007, 2008; and Setiawan et al. 2018).

Studies using geophysical methods that cover the Banyumas Basin area have also been carried out in Central Java, Indonesia. Based on the gravity horizontal gradient map, Widianto (2008) described the distribution of the tertiary sedimentary basin of Java region and

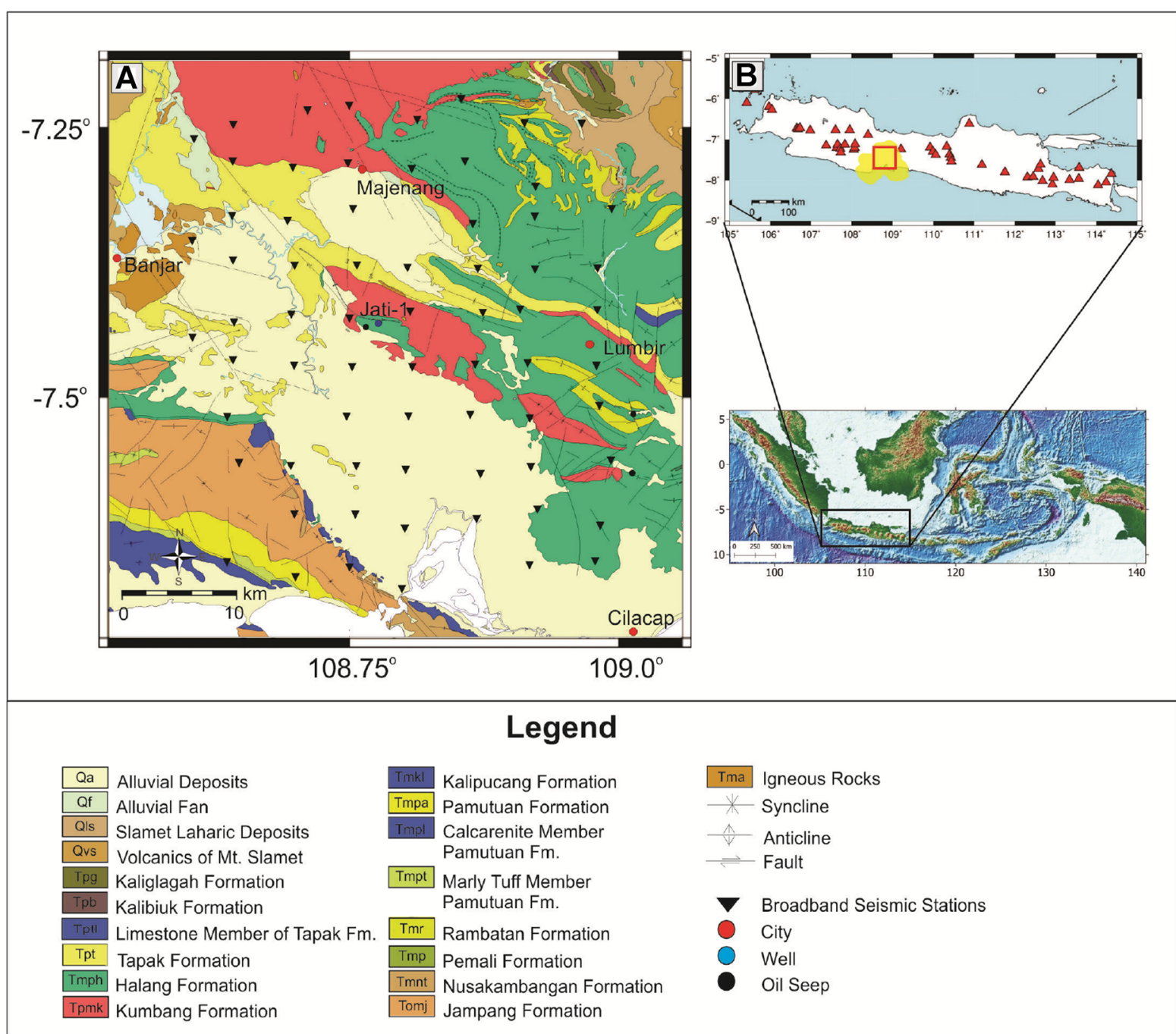

Fig. 1 A Geological map of the study area (modified from Simandjuntak and Surono 1992; Kastowo and Suwarna 1996; Djuri et al. 1996; Asikin et al. 1992); B inset map of survey location. The yellow area is the Banyumas Basin (Geologi 2009), the red square shows the survey location, and the red triangle is a volcano on Java Island 
focus on the basin area located in the south of Central Java which has several types of geological features. A study of seismic reflection has also been conducted in this area (Tampubolon et al. 2014). However, seismic reflection method gave a poor image of the subsurface structures in the Banyumas Basin due to the relatively thick volcanic deposits. In 2018, the Center for Geological Survey (CGS), Geological Agency, Indonesia, conducted an integrated survey using surface geology to identify elements of the petroleum system and geophysics to image the subsurface geological structure of the Banyumas Basin. Based on physical parameters of the rock density using gravity studies, Hidayat et al. (2020) also showed the delineation of the Citanduy subbasin and the Majenang sub-basin.

The relatively thick volcanic deposits present our main challenge in obtaining good subsurface images of this basin. Therefore, we attempted to apply another imaging method in this study, especially at shallow depths. We used ambient noise tomography (ANT) to obtain a subsurface image of the Banyumas Basin. ANT has been widely used by geophysicists to image shallow subsurface structures and showed better Vs structure resolution than the Vs structure from body wave tomography; e.g., the ANT result conducted by Rosalia et al. (2021) complemented the results of body wave tomography using global data (Widiyantoro and van der Hilst 1996) and regional data (Rosalia et al. 2019). Hidayat et al. (2021) used the arrival time of P and S waves from data recording about 6 months of 70 seismograph borehole stations for subsurface tomography and were able to show two sub-basins image and geological structures in the Banyumas Basin study area.

ANT using the cross-correlation of ambient seismic noise data records between two pair stations to obtain the Empirical Green's Function (EGF), which is associated with surface waves (Snieder and Wapenaar 2010; Paul et al. 2005; Snieder 2004; Wapenaar et al. 2010). ANT has been used extensively to image crustal structures in countries worldwide: Australia (Saygin and Kennet 2010), the Netherlands (Yudistira et al. 2017), China (Liu et al. 2016, 2017), Scotland (Nicolson et al. 2012), Tibet (Jiang et al. 2014; Zheng et al. 2017; Yao et al. 2009), and the United States (Ritzwoller et al. 2011; Luo et al. 2015). ANT has also been applied in Indonesia to determine $\mathrm{S}$-wave velocity structures in Jakarta Basin (Saygin et al. 2016), West Java (Rosalia et al. 2021), Central Java (Zulfakriza et al. 2014), East Java (Martha et al. 2017), the Bandung Basin (Wuryani et al. 2019; Pranata et al. 2020), as well as on the islands of Bali (Zulfakriza et al. 2020), and Lombok (Sarjan et al. 2021), and the Banda Arc (Porritt et al. 2016).
ANT studies of a sedimentary basin area are relatively limited in Indonesia, especially in a basin that has a thick volcanic layer. Although the ANT regional study done by Rosalia et al. (2021) included the Banyumas Basin, as well as the northwest-southeast trending regional structure, these results could not describe the subsurface images of the Banyumas Basin in detail. In this study, we used a greater number of local ambient seismic noise data sets recorded by 68 local stations with 60 days of observation between June and July 2018 to obtain more detailed images in the Banyumas Basin. We aimed to delineate the sediment deposits characterized by the low Vs pattern and present a vertical shear-wave velocity structure beneath the Banyumas Basin, as well as to determine the thickness of the sedimentary rocks in the area. Our results are useful in providing additional knowledge regarding the exploration challenges in the Banyumas Basin.

\section{Geological settings}

Geologically, the study area (Fig. 1) is predominantly covered with alluvial deposits and sedimentary rocks from the Halang Formation. The sedimentary rocks of the Halang Formation consist of tuffaceous sandstones, conglomerates, marls, clay stones, and andesitic breccias at the bottom level. There are also volcaniclastic products from the Kumbang Formation of the same age as that of the Halang Formation (Middle Miocene-Pliocene), which consist of volcanic breccias, lava, dykes, and tuffs composed of andesite and basalt. The Kumbang Formation connects with the Halang Formation and overlaps the Kalipucang Limestone (Middle Miocene). Above the sequential Halang Formation are several Pliocene formations, which consist of: the Kalibiuk Formation, which consists of clay and marl deposits; the Kaliglagah Formation, which consists of coarse sandstone and conglomerate deposits; and the Tapak Formation, which consist of coarse sandstone sediment with marl intercalations. Quarterly volcanic products and alluvial deposits can be found at the top of these formations (Kastowo and Suwarna 1996).

The older formation underneath the Halang Formation consists of the Rambatan Formation, the Pemali Formation (the term "Penanjung Formation" was first used by Setiawan 2019), the Nusakambangan Formation, and the Jampang/Gabon Formation. The Rambatan Formation (Middle Miocene) consists of sedimentary sandstone and conglomerate with marl and shale (Kastowo and Suwarna 1996). The Penanjung Formation (Middle Miocene) consists of carbonate claystone with sandstone intercalations. The Nusakambangan Formation (Early Miocene) consists of carbonate claystone with tuffaceous sandstone intercalations (Setiawan 2018). The Gabon Formation 
(Oligocene-Early Miocene) consists of breccia volcaniclastic deposits with pieces of andesite in a tuff/sand matrix (Asikin et al. 1992). The geological map of the survey area (Fig. 1) reveals that the Halang, Kumbang, and Tapak Formations, as well as the alluvial deposits, tend to trend in a northwest-southeast direction.

Volcanic products and sedimentary deposits presented in the Banyumas Basin were close to the tectonic and volcanism periods that occurred in this area. Purwasatriya et al. (2019) argued that the Banyumas Basin was a type of island arc flexure basin because the basin was formed between volcanic islands in the middle of the sea. The authors were quite detailed in reviewing the history of Banyumas Basin, including:

- Late Cretaceous-Middle Eocene period: the Banyumas Basin was still a subduction zone between the Indo-Australian oceanic plate and Sundaland continental plate;

- Middle Eocene-Late Oligocene period: the subduction path was a relatively east-west direction;

- Late Oligocene-Early Miocene period: the southern mountains in Java were formed. This mountain range limited the southern part of the Banyumas Basin and there were already older sedimentary deposits. Volcanic material deposits that filled the Banyumas Basin were very abundant during this period;

- Early Miocene-Middle Miocene period: volcanic activity in previous period has subsided. While marine deposits from the north filled the Banyumas Basin;

- Middle Miocene-Pliocene period: volcanic activity in the Mio-Pliocene magmatic arc started to form in the middle of the Banyumas Basin and provided material supply to the basin. In addition, erosion material from the southern mountains and marine sediment deposits from the north was still ongoing;

- Pliocene-Pleistocene period: the subducting plate moved further north and a magmatic arc formed north of the Mio-Pliocene magmatic arc.

\section{Data and method \\ Data}

We used waveform data from the seismic network deployed by the Center for Geological Survey (CGS), Geological Agency, Indonesia. The seismic network used 68 portable $3-\mathrm{C}$ broadband borehole seismic stations in an area of less than 0.5 square degrees within the Banyumas Basin area, which was south of Central Java, Indonesia (Fig. 1). The data used were the records of June and July 2018. The minimum and maximum distances between the seismometer stations are 5 and
$58 \mathrm{~km}$, respectively. The waveform data were collected every 2 weeks; the batteries were replaced, and the seismometers checked in the same 2-week timeframe. In this study, we utilized only those Rayleigh waves that were obtained from the cross-correlation results of the noise data between station pairs. As a result, only the vertical component of the waveform data was used in the processing steps.

Several steps were first carried out before each seismometer was installed. Firstly, a drill hole at the location of the seismometer station was drilled; these averaged a depth of $12 \mathrm{~m}$. Secondly, the base of the borehole was cemented with mortar to make it easier to securely couple the seismometer. Thirdly, a 2.5-in.-diameter pipe was inserted into the drill hole. Fourthly, the seismometer was inserted into the drill hole. The last step was filling the pipe with water to reduce noise from human activities.

To ensure safekeeping, the seismometers were located in the yards of selected residents, while the recording instruments were placed inside their houses. The seismic data were recorded and stored on a 16-GB removable flash disk (micro-SD card). A real-time GPS was also connected to each recording instrument to record data in real-time. Another process that was also carried out was differential GPS measurements above the location of each of the seismometers to determine the location and height of the seismometer locations in greater detail.

\section{Ambient noise cross-correlation and group velocity extraction}

Ambient seismic noise interferometry refers to the process of cross-correlation between two sets of ambient seismic noise data that are recorded by two receivers in an acoustic diffusion wavefield to produce EGF at the receiver position as if one of the stations acts as the source (Wapenaar et al. 2006, 2010; Curtis et al. 2006). Ambient seismic noise data recording has an advantage since it does not require earthquake sources, which means it can be measured at any time and anywhere (Curtis et al. 2006; Yang and Ritzwoller 2008). Yang and Ritzwoller (2008) also show that ambient noise sources generally take place over a short period $(<20 \mathrm{~s})$ and are considered to be related to the interaction between ocean waves near the coastline and the ocean floor. Generally, two maximum-sized peaks of short-term seismic noise were observed in the primary (10-20 s) and secondary microseismic (5-10 s) time ranges.

The procedure for processing ambient seismic noise data follows Saygin and Kennet (2010), which were also used by Zulfakriza et al. (2014 and 2020). This procedure looks similar to that done by Bensen et al. (2007), but we did not modify the spectrum with one-bit normalization and spectral whitening in preparing single-station data 
to extract Green's function. The cross-correlation process between two stations, $X_{A}$ and $X_{B}$, could be written in a mathematical formulation as could be seen in Saygin and Kennet (2010). We obtained 2278 potential crosscorrelation pairs of 68 broadband portable stations using 60 days of continuous seismic data, in order to determine the Vs velocity structure beneath the Banyumas sedimentary basin. We applied narrow Gaussian band technique in the period range 5-10 $\mathrm{s}$ for each EGF to determine arrival time (Fig. 2A).

Surface waves have dispersive characteristic and allow us to observe the group velocity for different periods. By applying the Multiple Filter Technique (MFT) that introduced by Dziewonski et al. (1969), we could estimate the dispersion curve of each station pairs. We picked group velocity in different period manually as an input for tomographic inversion of group velocity.

We picked about 1291 of 2278 EGF which was clearly of dispersion curve and we ignored the noisy packet. We rejected more than 1000 EGF (Additional file 1: Fig. S1), which was manually picked from the amplitude peak of group velocity envelope in the fundamental mode (Fig. 2B).

We refer to Luo et al. (2015) who applied ambient noise data of USArray during 2007-2012, and based on dispersion measurement of time-domain cross-correlation with short interstation distances. The result looks consistent and reliable on the criterion of the three wavelengths. For the average velocity of the Rayleigh wave group, about $1.4 \mathrm{~km} / \mathrm{s}$ with a maximum period of $5 \mathrm{~s}$, the minimum interstation distance is about $7 \mathrm{~km}$. In this study, the criterion of the distance interstation between $\mathrm{C} 01$ and $\mathrm{C} 02$ with one wavelength is shown in Fig. 2B. The distance from these stations is approximately $10.175 \mathrm{~km}$ and the average group velocity $\sim 1.74 \mathrm{~km} / \mathrm{s}$ with 5.85 -s periods. The maximum period of group velocity propagation matches with the maximum period of FTAN analysis, as shown in Fig. 2B.

\section{Group velocity inversion}

We used the Fast Marching Surface Tomography (FMST) package from Rawlinson (2005) to obtain variations in the Rayleigh surface wave velocity. The Fast Marching Method (FMM) was used for forward calculation, then we applied subspace scheme for the inversion stage. FMM is a grid-based schema for solving eikonal equations, using a finite-difference based on Rawlinson and Sambridge (2005), which is the most effective method of accurately tracking waveforms to determine the travel time of ray paths passing through a medium at heterogeneous velocities. The subspace inversion method is also an iterative method, part of a class of highly effective
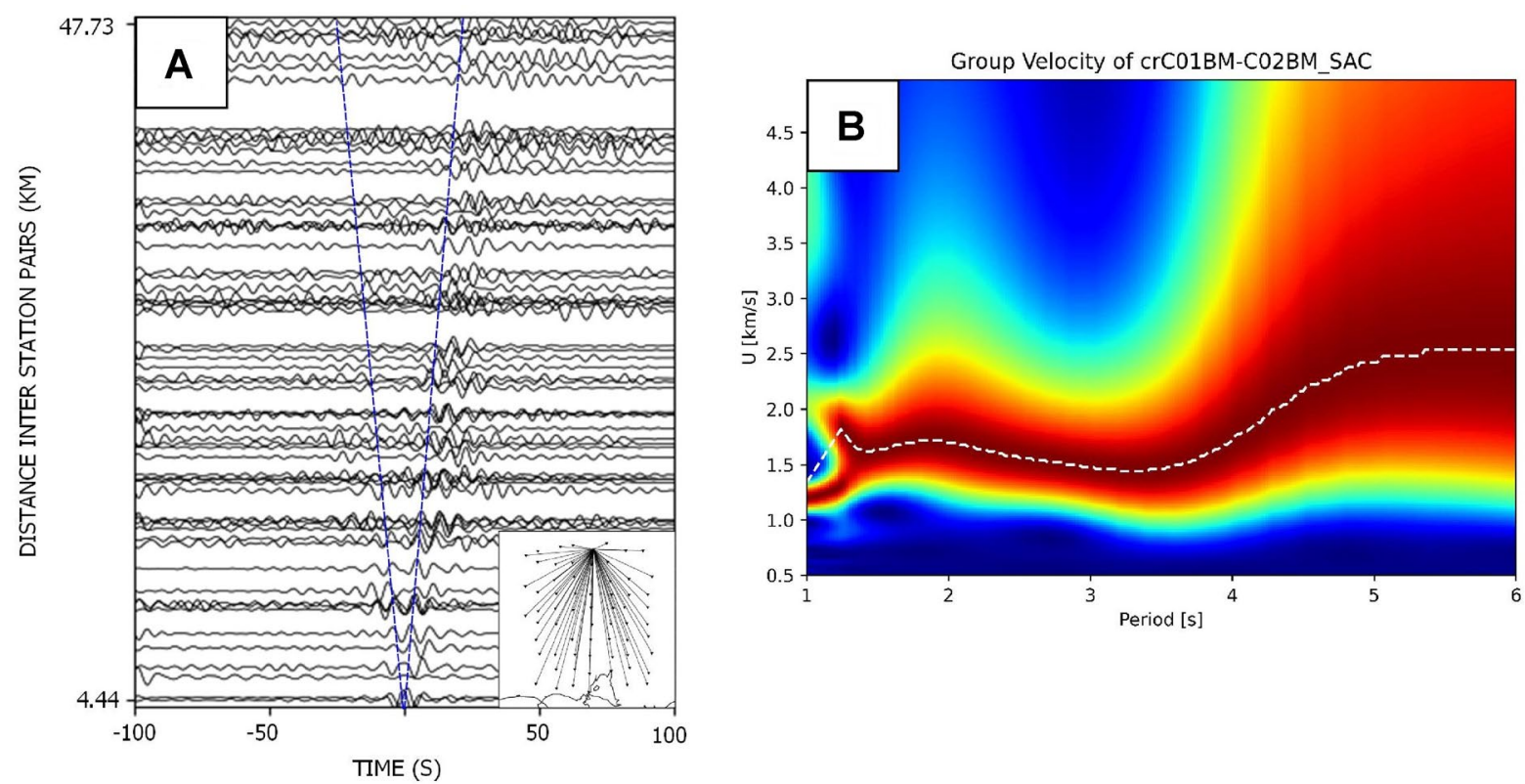

Fig. 2 A Cross-correlogram between station pairs C33 against all possible receiving stations with an average Rayleigh wave velocity of $2.12 \mathrm{~km} / \mathrm{s}$. The position between station C33 and the other stations is indicated on the inset map. The blue dashed line indicates the lag time trend of the Rayleigh EGF waves as the distance between stations increased. B The dispersion curve of the EGF picking process between stations C01-C02. The white dashed line indicates the result of group velocity picked at the top of the envelope, with the red area denoting the maximum energy possessed by the Rayleigh wave 
algorithms that minimizes objective/misfit functions using a quadratic approximation of the parameter space model in a relatively small dimension (Kennett et al.1988). This method has been successfully applied to produce velocity variation maps of the Rayleigh group (Saygin and Kennet 2010; Martha et al. 2017; Zulfakriza et al. 2020).

The objective functions $S(\mathrm{~m})$ that are minimized during the inversion process can be written as follows:

$$
\begin{aligned}
S(\mathrm{~m})= & \left(g(\mathrm{~m})-d_{o b s}\right)^{T} C_{d}^{-1}\left(g(\mathrm{~m})-d_{o b s}\right) \\
& +\varepsilon\left(\mathrm{m}-\mathrm{m}_{0}\right)^{T} C_{\mathrm{m}}^{-1}\left(\mathrm{~m}-\mathrm{m}_{0}\right)+\eta \mathrm{m}^{T} D^{T} D \mathrm{~m}
\end{aligned}
$$

where $\mathrm{m}$ is an unknown model parameter vector (such as group velocity), $g(\mathrm{~m})$ is the predicted travel time of the group velocity, $d$ is the observed travel time of the group velocity, $C_{\mathrm{d}}$ is the covariance data matrix, $\mathrm{m}_{0}$ is the reference model, $C_{\mathrm{m}}$ is the model parameter covariance matrix, $D$ is a smoothness matrix, $\varepsilon$ is a damping parameter, and $\eta$ is a smoothing parameter.

\section{Depth inversion}

We applied the Neighbourhood Algorithm (NA) introduced by Sambridge (1999a, b) to determine the variation of 1D shear-wave velocity from the surface wave dispersion curve inversion. NA is a nonlinear inversion method classified as a direct search method and is considered capable of solving inversion problems that have quite complex relationships between observational data and unknown model parameters. The NA direct search inversion method is divided into two stages. First, the search stage, which samples multi-dimensional parameter space to find a combination of model parameters that are suitable for observational data. Second, the appraisal stage which extracts information from the complete ensemble of collected models to find a single optimal model. The search algorithm used by NA is in the same classification as the GA and SA techniques; namely, randomly searching for the decision function of the misfit instead of using derivative calculations in the misfit data function (freederivative misfit function) (Sambridge 1999a, b).

Wathelet et al. (2008) successfully applied NA to produce new computer code for creating inversions of Rayleigh surface wave dispersion curves. The NA inversion algorithm was also used by Zulfakriza et al. (2020) to produce Vs variations to describe tomography beneath the Agung-Batur volcanic complex on Bali Island. The author was able to show the presence of low Vs between Mt. Agung and Mt. Batur to a depth of $2 \mathrm{~km}$. This low velocity was interpreted as an accumulation of low Vs volcanic deposits and the presence of over-pressurized hydrothermal fluids.
In this study, we used the $\mathrm{Vp}$ of checkshot velocity data obtained from measurements at the Jati-1 well location (Fig. 1) as the initial search model. The depth of the well from the recorded checkshot information is approximately $4.3 \mathrm{~km}$ with a Vp value range from 2.5 to $3.3 \mathrm{~km} / \mathrm{s}$. We obtained the Vs value of the Jati-1 well by applying the empirical ratio of $\mathrm{Vp} / \mathrm{Vs} 1.74$ which was calculated from travel time tomography data processing (Hidayat et al. 2021). We also used a velocity model from CRUST 1.0 (Laske et al. 2013) which is limited to the second layer and crystal crust 1 at a depth of $11.66 \mathrm{~km}$. The minimum and maximum Vs values obtained from the CRUST 1.0 model are $0.88 \mathrm{~km} / \mathrm{s}$ and $3.4 \mathrm{~km} / \mathrm{s}$, respectively.

\section{Results}

\section{Checkerboard resolution test}

We used a checkerboard resolution test (CRT) in a checkerboard pattern of low- and high-velocity groups as an initial model to determine how well the study area could be recovered. We conducted several checkerboard cell sizes to test the proper resolution sizes as indicated by the checkerboard pattern's recovery in this study. The optimum cell sizes were then applied to each period to obtain the tomographic image of the velocity of the Rayleigh wave group.

We conducted three checkerboard resolution tests using different cell dimensions: $~ 8.5 \quad \mathrm{~km} \times 8.5 \quad \mathrm{~km}, \sim 6.5 \quad \mathrm{~km} \times 6.5 \quad \mathrm{~km}$, and $\sim 5.5 \mathrm{~km} \times 5.5 \mathrm{~km}$, as shown in Fig. 3. The three CRT experiments all used the same parameter. The results showed good recovery of the checkerboard pattern on the inside of the station network, compared to outside the station network. The checkerboard recovery results using a $\sim 5.5-\mathrm{km}^{2}$ cell size showed a smearing effect compared to the other cell sizes. Therefore, we decided to use the $\sim 6.5-\mathrm{km}^{2}$ grid cell size as the optimum resolution size to be recovered in the study area. By using a $\sim 6.5-\mathrm{km}^{2}$ grid cell size, we expected to image the study area's complex geological conditions in greater detail, as compared to previous studies.

Damping and smoothing parameters are important parameters for solving the optimum solution of the inversion of Eq. 1. We tested the damping parameter values of $10-5000$ and the smoothing parameter values of 5-3000 through the trade-off curve (Additional file 1: Fig. S2) and obtained an optimum value of 300 and 300, respectively. The Additional file 1: Fig. S3 image showed the results of the checkerboard resolution test at different periods, using a $\sim 6.5-\mathrm{km}^{2}$ grid cell size, a damping parameter of 300 , and a smoothing parameter of 300 . The results showed that the checkerboard recovery pattern was sufficient in periods $1 \mathrm{~s}$ to $6 \mathrm{~s}$. In contrast, in periods 


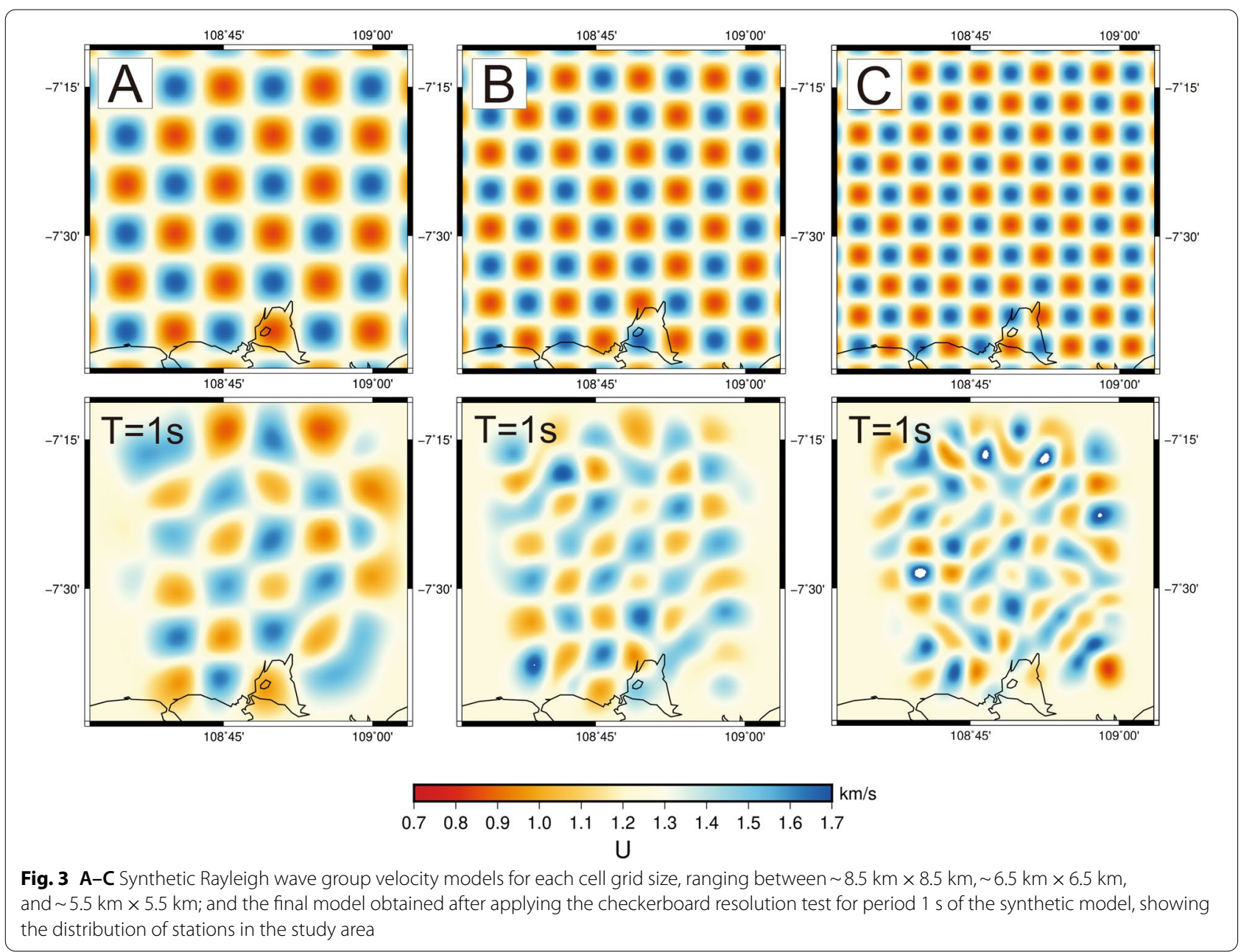

higher than $6 \mathrm{~s}$, the recovery pattern was insufficient for indicating a recovery of the checkerboard pattern.

\section{Rayleigh wave group velocity maps}

Tomographic inversion was performed on the observed travel time data extracted from the dispersion curve to determine Rayleigh wave group velocity variation in periods $1 \mathrm{~s}$ to $6 \mathrm{~s}$. Figure 4 shows the distribution map of the group velocity variation of the Rayleigh wave in the study area in periods $1 \mathrm{~s}$ to $6 \mathrm{~s}$. We use the same parameter that is used in the optimum of CRT. The Rayleigh wave group velocity map produced a high-resolution velocity model within the station network due to the large numbers and high density of the ray paths (shown in the inset map of Fig. 4). In this study, periods longer than $6 \mathrm{~s}$ were not used because the result of the 6-s period already had low resolution associated with a reduced amount of ray path coverage (Additional file 1: Fig. S4).

The geological features of the group velocity map of the Rayleigh wave in Fig. 4 showed the presence of two low group velocity values which was separated by high group velocity and had northwest-southeast trending structures. The low group velocity might correspond to relatively thick sedimentary rocks in the area which was evidenced by the distribution of the alluvial sedimentary layer, Halang, Kumbang, and Tapak Formations and coincide with the depocenter of the Majenang Low (northwest) and the Citanduy Low (southeast). In addition to the high group velocity anomaly that separated the two low group velocities, other high group velocities were also present in the southwest and northeast.

\section{Shear-wave velocity model}

As mentioned above, we successfully developed group velocity map for range period $1 \mathrm{~s}$ to $6 \mathrm{~s}$ (Fig. 4). We applied NA scheme (Sambridge 1999a, b) to produce 1D shear-wave velocity profile at various depth (Fig. 5). There were 121 points covering the Banyumas basin which intervals 0.05 degree $(\sim 5.5 \mathrm{~km})$ of each point. We 


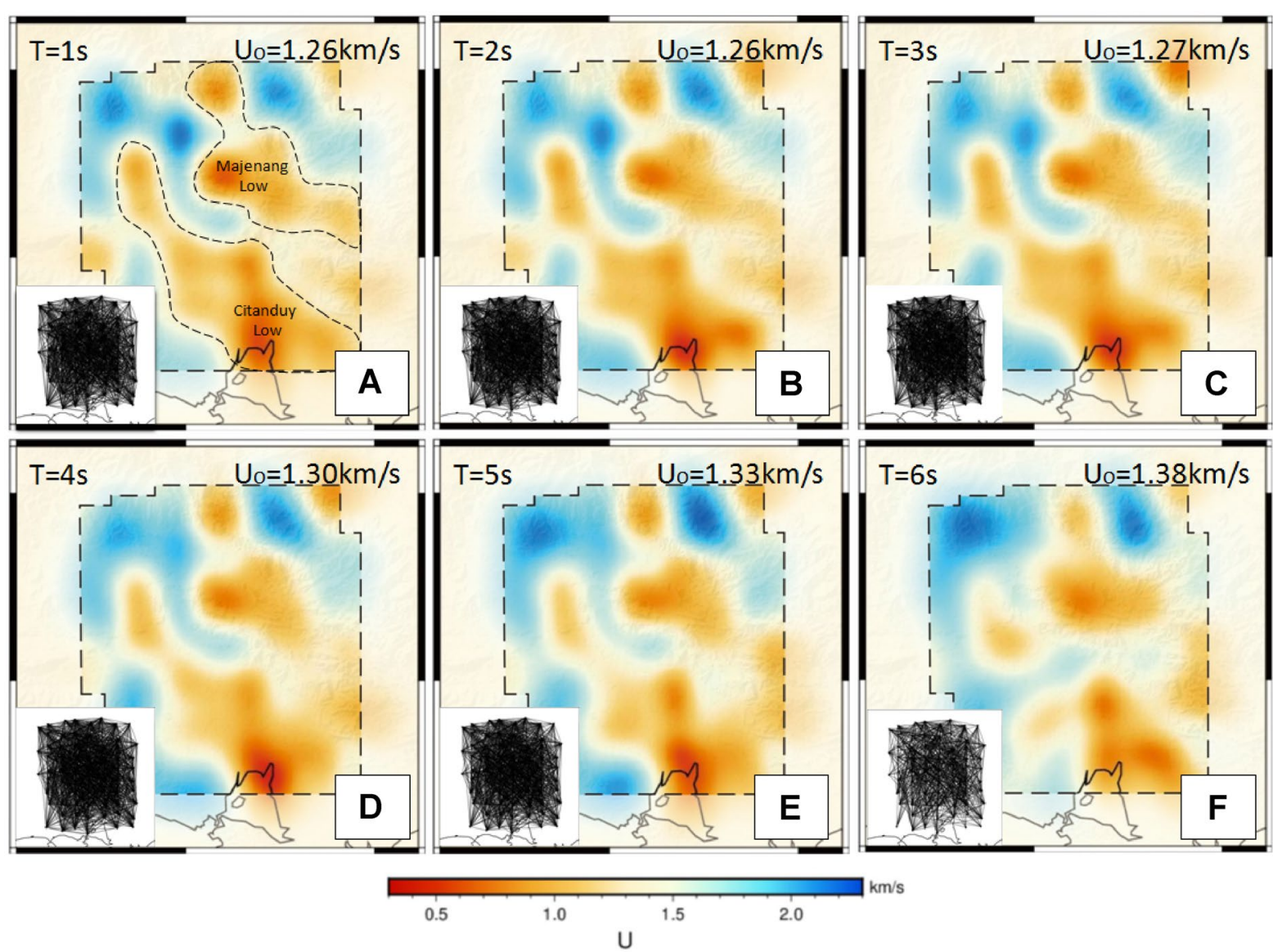

Fig. 4 A-F The Rayleigh wave group velocity map at periods $1 \mathrm{~s}$ to $6 \mathrm{~s}$. The ray path was shown in the inset map. The low group velocity, high group velocity, and the developing structures in this area tend to trend northwest-southeast

used dinver package of Geopsy software that developed by Wathelet et al. (2008).

Several parameters needed to be determined in the 1D Vs inversion process; e.g., the total thickness model for the Earth's layer, the range of velocity of the search model, and the range of thickness of the Earth's layer. In this study, we used five layers of parameters for the NA inversion process with different velocity values of Vs and depth thickness. The range of uniform Vs model parameters used for each layer were: $500-1300 \mathrm{~m} / \mathrm{s}$, $700-2000 \mathrm{~m} / \mathrm{s}, 1000-2300 \mathrm{~m} / \mathrm{s}, 1400-2500 \mathrm{~m} / \mathrm{s}$, and $2000-3500 \mathrm{~m} / \mathrm{s}$. The model parameters for the thickness of each layer were: $200-1290 \mathrm{~m}$ (bottom depth), with the other three layers in the thickness range of 1290-1500 m, $1500-2000 \mathrm{~m}$, and 2000-4000 $\mathrm{m}$.

Figure $5 \mathrm{~A}-\mathrm{C}$ shows three examples of the $1 \mathrm{D}$ Vs vertical profile obtained by applying the Neighbourhood Algorithm. Figure 5D shows the location of three examples of 1D Vs. Figure 5A shows a gradual increase in the Vs values with increasing depth from the surface, as can be seen in the 1D Vs profile in Fig. 5B, C. After the inversion of the dispersion curve on all 121 grid points, we did an interpolation to obtain a 2D Vs map at depths of $0.5-8 \mathrm{~km}$ (Fig. 6). The low Vs pattern that appeared on the group velocity map of the Rayleigh wave was consistent with the map of Vs value distribution to a depth of $3 \mathrm{~km}$ (Fig. 6A-D) and tended to trend in the northwestsoutheast direction; whereas higher Vs were dominant at depths of more than $3 \mathrm{~km}$.

\section{Discussion}

We showed the 1D profile inversion from 3 different locations in Fig. 5: in the northern part characterized by high group velocity (Fig. 5A), then Majenang Low (Fig. 5B) and Citanduy Low (Fig. 5C) characterized by a low group velocity. The misfit of objective function between observed (white curve line) and calculated (black curve line), respectively, shows a value of less than 0.1 . The quantitative value of the calculation closed to the observed result and showed the best model that could be obtained. The 1D Vs profile showed a gradual velocity change to the depth below the surface. Changes in the 

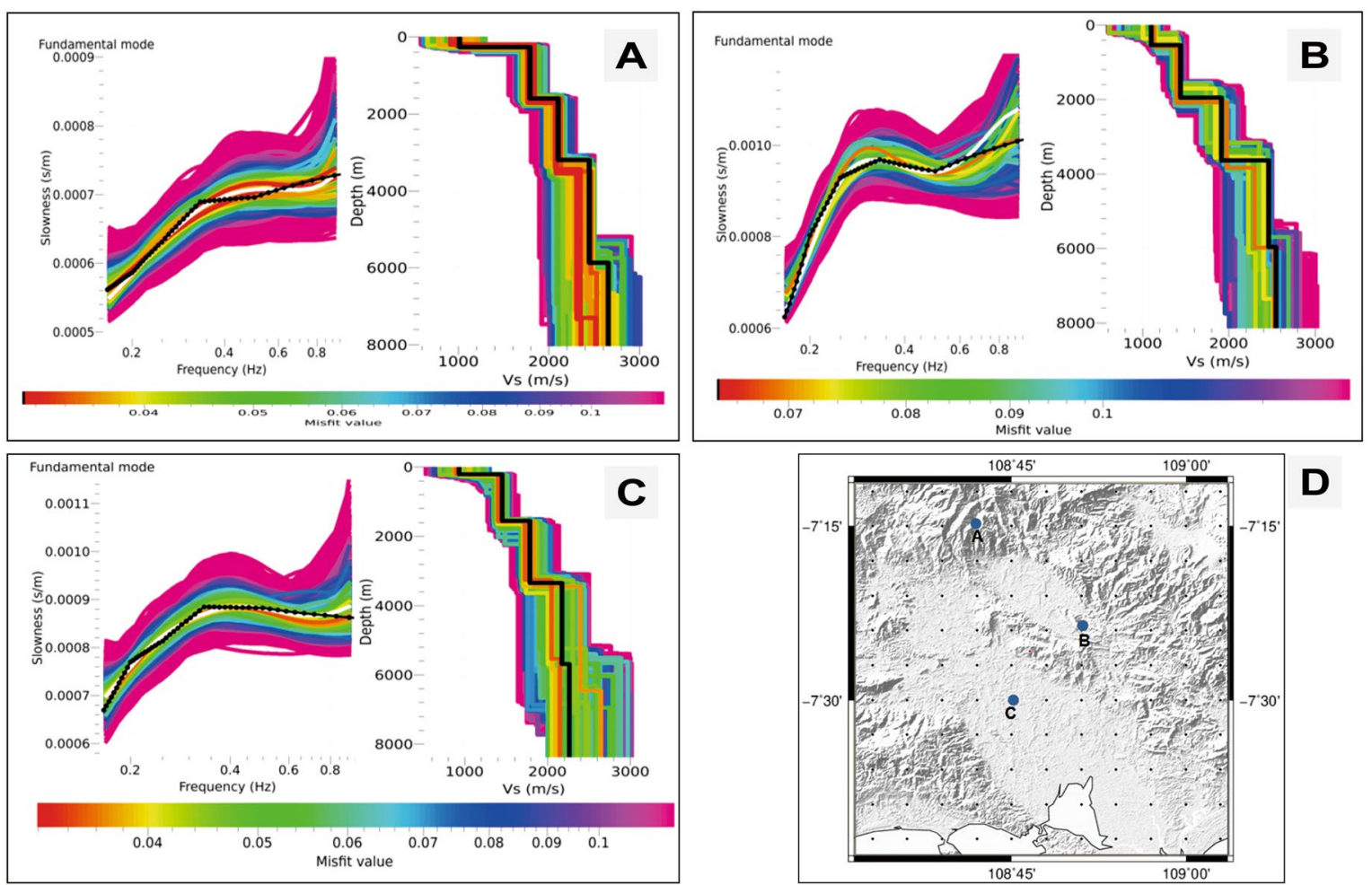

Fig. 5 A-C Three examples of dispersion curve inversions at three different locations; $\mathbf{D}$ coordinates of three examples (denoted by blue dots) of the application of dispersion curve inversion in the study area. Small, gray dots denote the 121 grid points of the dispersion curve inversion

value of $1 \mathrm{D}$ Vs were interpreted as a response to changes in rock lithology or formation. The Vs value was reached at depth of $8000 \mathrm{~m}$ in Fig. 5A, which was about $2700 \mathrm{~m} / \mathrm{s}$, shallower than the Vs value that was achieved in Fig. 5B, C. This showed the possibility that rock layers with higher velocity structures could be found at shallower depths than in Fig. 5B, C. From Fig. 5, we also observed that there was a possibility that the response tendency of the low anomaly Vs extended to the middle of the study area.

Figure 5B, C was likely to be in a response area having the value of Vs in an area covered by Quaternary deposits that trended northwest-southeast. Based on the response of the value of Vs produced at the same depth of $8000 \mathrm{~m}$, Fig. 5B produced a Vs response value up to $2500 \mathrm{~m} / \mathrm{s}$, while Fig. $5 \mathrm{C}$ produced a response value of $\mathrm{Vs}$ up to $2200 \mathrm{~m} / \mathrm{s}$. This indicated the possibility of thicker sedimentary layers leading southeast. In Fig. 5A-C, it also could be seen the highest Vs value that obtained at $\sim 6000 \mathrm{~m}$ of depth, with possibility of a rock structure discontinuity boundary. We also noted that the dispersion calculation curve in the fundamental mode of Fig. $5 \mathrm{~A}-\mathrm{C}$ was relatively matched, following the change in velocity at $0.6-1 \mathrm{~Hz}$ frequencies. This indicated that the computational limitations in the frequency range were dependent on the grid size used.

The explanation of the results from Fig. 5 could be clarified by the 2D Vs profile in Fig. 6 . The low anomaly Vs $(0.4-1.7 \mathrm{~km} / \mathrm{s})$ was estimated as the response of the Middle Miocene-Pliocene rock distribution (Kumbang, Halang, and Tapak Formations). At the same time, the response of the quaternary rocks, which was likely at a depth range of $0-0.5 \mathrm{~km}$, could not be resolved in this work. The medium anomaly Vs $(1.71 \mathrm{~km} / \mathrm{s}-2.3 \mathrm{~km} / \mathrm{s})$ was estimated as a response of Early-Middle Miocene sedimentary rocks (Nusakambangan, Penanjung, and Rambatan Formations). On the other hand, the high anomaly $(2.31 \mathrm{~km} / \mathrm{s}-2.7 \mathrm{~km} / \mathrm{s})$ was estimated as a response of the Oligocene-Early Miocene rocks (volcanic products of the Gabon Formation).

In the tomogram map of Vs model in Fig. 6, it could be seen that pattern of low-velocity anomaly at northwestsoutheast, we interpreted as Majenang Low and the Citanduy Low. The Majenang Low was located relatively in the north, otherwise the Citanduy Low was located in the south of Banyumas Basin at depths of $0.5-3 \mathrm{~km}$ depth (Fig. 7A). We described the Vs structure at $0.5-8 \mathrm{~km}$ depth in vertical cross section (Fig. 7) and utilized the 

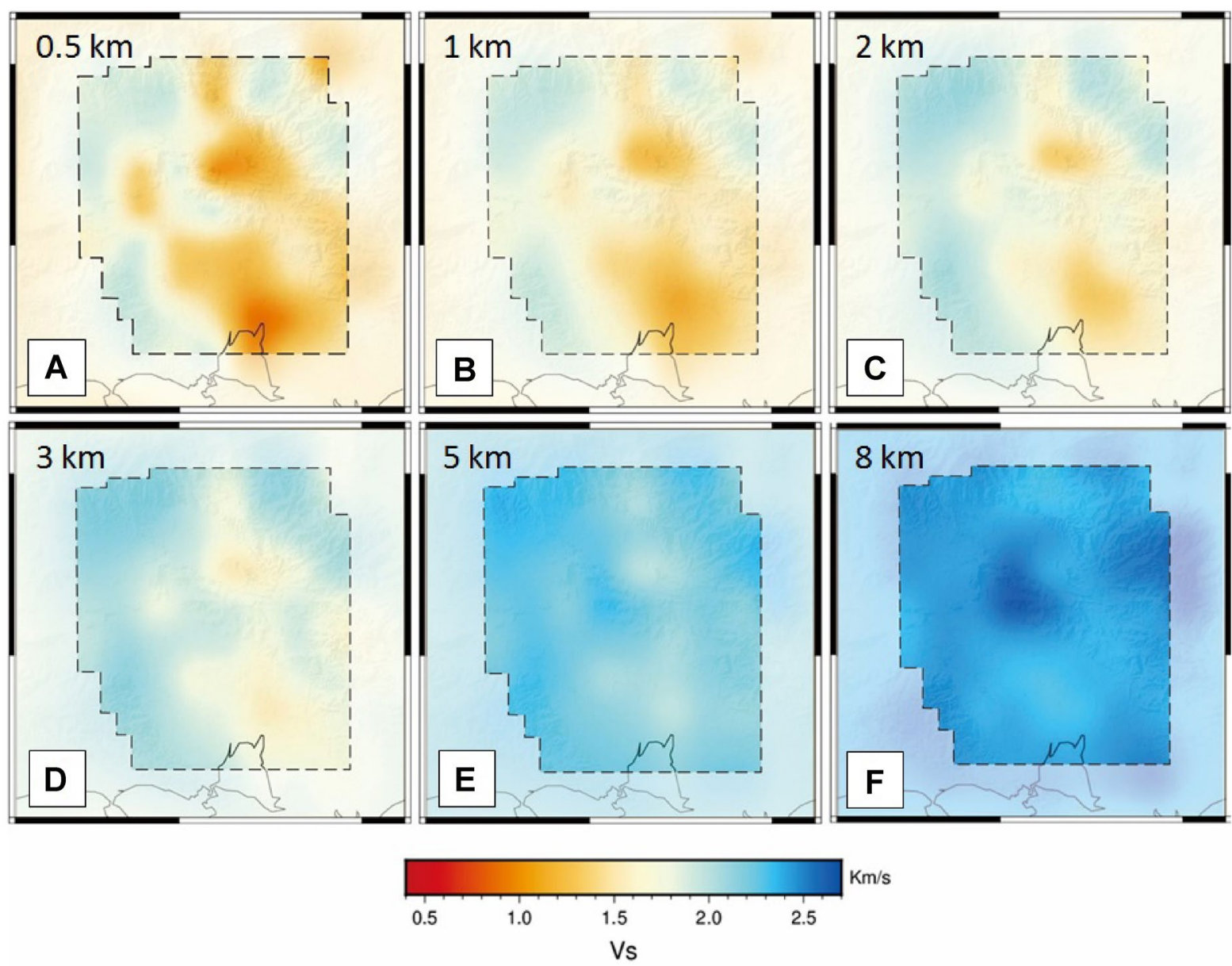

Fig. 6 Shear-wave velocity (Vs) maps at various depths, A $0.5 \mathrm{~km}, \mathbf{B} 1 \mathrm{~km}, \mathbf{C} 2 \mathrm{~km}, \mathbf{D} 3 \mathrm{~km}, \mathbf{E} 5 \mathrm{~km}$, and $\mathbf{F} 8 \mathrm{~km}$

facies analysis of Jati-1 well log data from Tampubolon et al. (2014) (Additional file 1: Table S1).

We identified shear-wave velocity range of $\sim 0.8$ $1.7 \mathrm{~km} / \mathrm{s}$ at first layer of A-A' lines (Fig. 7A) which corresponded to Middle Miocene-Pliocene rock response (Kumbang, Halang, and Tapak Formations) as shown in Fig. 1. Then at the second layer (Fig. 7A), the contrast of shear-wave velocity range of $\sim 1.7-2.3 \mathrm{~km} / \mathrm{s}$ possibly related to as the Early-Middle Miocene rock response (Nusakambangan, Penanjung, and Rambatan Formations). For the third layer of $\mathrm{A}-\mathrm{A}^{\prime}$ cross section where the shear-wave velocity was faster than $2.3 \mathrm{~km} / \mathrm{s}$ could be influenced by igneous rocks beneath the Nusakambangan Formation. Explanations of the first, second, and third layers in Fig. 7 (lines B-B') followed the vertical cross section of lines A-A.'

Subroto et al. (2007) and Setiawan et al. (2018) estimated the existence of Eocene sediment which had potential as source rock in the Banyumas Basin, indicating the possible existence of further rock layers beneath the Gabon Formation. Then, the third layer of A-A' profile could be identified as volcanic products of Gabon Formation (Oligocene-Early Miocene) and Eocene sediment. The characteristics of rock boundary between volcanic products and Eocene sedimentary rocks had a contrasting shear-wave velocity. Unfortunately, we could not delineate this boundary clearly due to limitation of resolution in our model.

Setiawan et al. (2018) stated that the volcanic data obtained, namely the Gabon Formation, showed tholeiitic affinity and had a basaltic composition that was associated with an oceanic island/volcanic arc. At the same time, Christensen and Stanley (2003) showed that the value of $\mathrm{Vp}$ and $\mathrm{Vs}$ for each type of rock; the results of their study also showed the minimum $\mathrm{Vp}$ and Vs values for basaltic rocks, which was about $5.9 \mathrm{~km} / \mathrm{s}$ and $3.2 \mathrm{~km} / \mathrm{s}$. From these studies, we estimated that the results of our model had not yet reached the basement because the highest Vs value that could be achieved was still lower than the Vs value of rock test results at the 


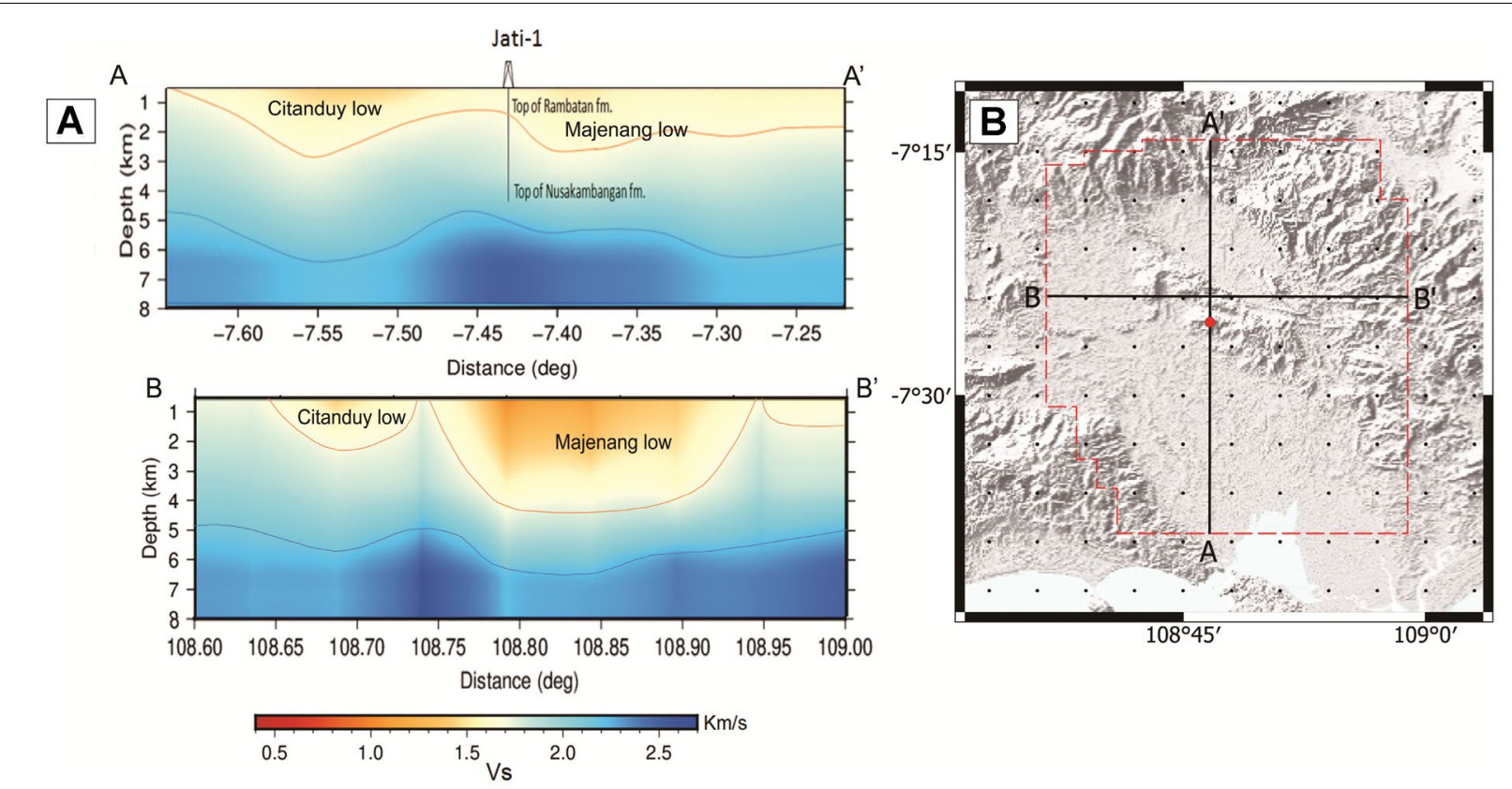

Fig. 7 A Vertical cross section of Vs structure for lines $A-A^{\prime}$ and $B-B^{\prime}$ at longitude $107.776^{\circ}$ and latitude $-7.4^{\circ}$; B Position of lines $A-A^{\prime}$ and $B-B^{\prime}$ on the map is denoted by black lines, the red dashed lines are the limits of the ANT tomographic resolution, and the red dot is the location of the Jati-1 well

pressure of $200 \mathrm{MPa}$ obtained by Christensen and Stanley (2003).

Furthermore, we compared our model with other geophysical and geological methods (Fig. 8). We could identify two patterns of low Vs anomaly, they were Majenang Low and Citanduy Low which were located at northwest-southeast direction and separated by the Cipari Anticline. The depocenter of the Majenang Low was estimated to be northwest of the area, while the depocenter of the Citanduy Low was estimated to be southeast of the area. These were marked by Vs anomaly values that were lower than the surrounding points. The pattern and direction of the low Vs were relatively the same as the pattern of the low Bouguer anomaly shown in Fig. 8B. Rocks with a low-density value compared to the surrounding rocks will tend to respond to low Bouguer anomalies and also tend to respond to low Vs values if propagated by a surface wave. The strike-slip faults southwest and northeast of the study area were interpreted as the Citanduy (written as Citandui in Simandjuntak and Barber 1996) and the Karangbolong Faults. This interpretation was reinforced by Muchsin et al. (2002), as shown in Fig. 8C. On the geological map (Fig. 1A), the Citanduy fault was not depicted well enough on the surface. This also showed that this fault was covered by sediment deposits after this fault was formed. The presence of the Citanduy and Karangbolong faults was quite well illustrated in the low-high boundaries of the Vs response and the Bouguer anomaly.

Hidayat et al. (2021) described two sub-basins in Banyumas basin, such as Majenang and Citanduy sub-basin, as well as the geological structures and they used the term "subbasin" for two low Vs areas, Majenang Low and Citanduy Low. However, our model had not been able to image the basement of the Banyumas basin as shown by Hidayat et al (2021) at average depth of $8 \mathrm{~km}$. Therefore, our model could provide additional information on possibility of sedimentary layer boundaries that had not been resolved with the travel time tomography method by Hidayat et al. (2021). The boundaries of this sedimentary layer were thought to be related to the period of tectonic and volcanism that occurred in the Banyumas Basin (Purwasatriya et al. 2019).

\section{Conclusions}

The ambient noise cross-correlation technique was successfully applied to the vertical component data of the seismic records carried out in the Banyumas sedimentary basin to produce the EFG of a Rayleigh wave. The characteristic of the ambient noise source obtained in this area was in the secondary microseismic range $(5 \mathrm{~s}-10 \mathrm{~s}$ period). Our model was able to delineate the subsurface structure of the Banyumas Basin, shown on the variations of Vs value at depths of $0.5 \mathrm{~km}$ to $8 \mathrm{~km}$. Based on the Vs value variation map, there were two low Vs values, which 


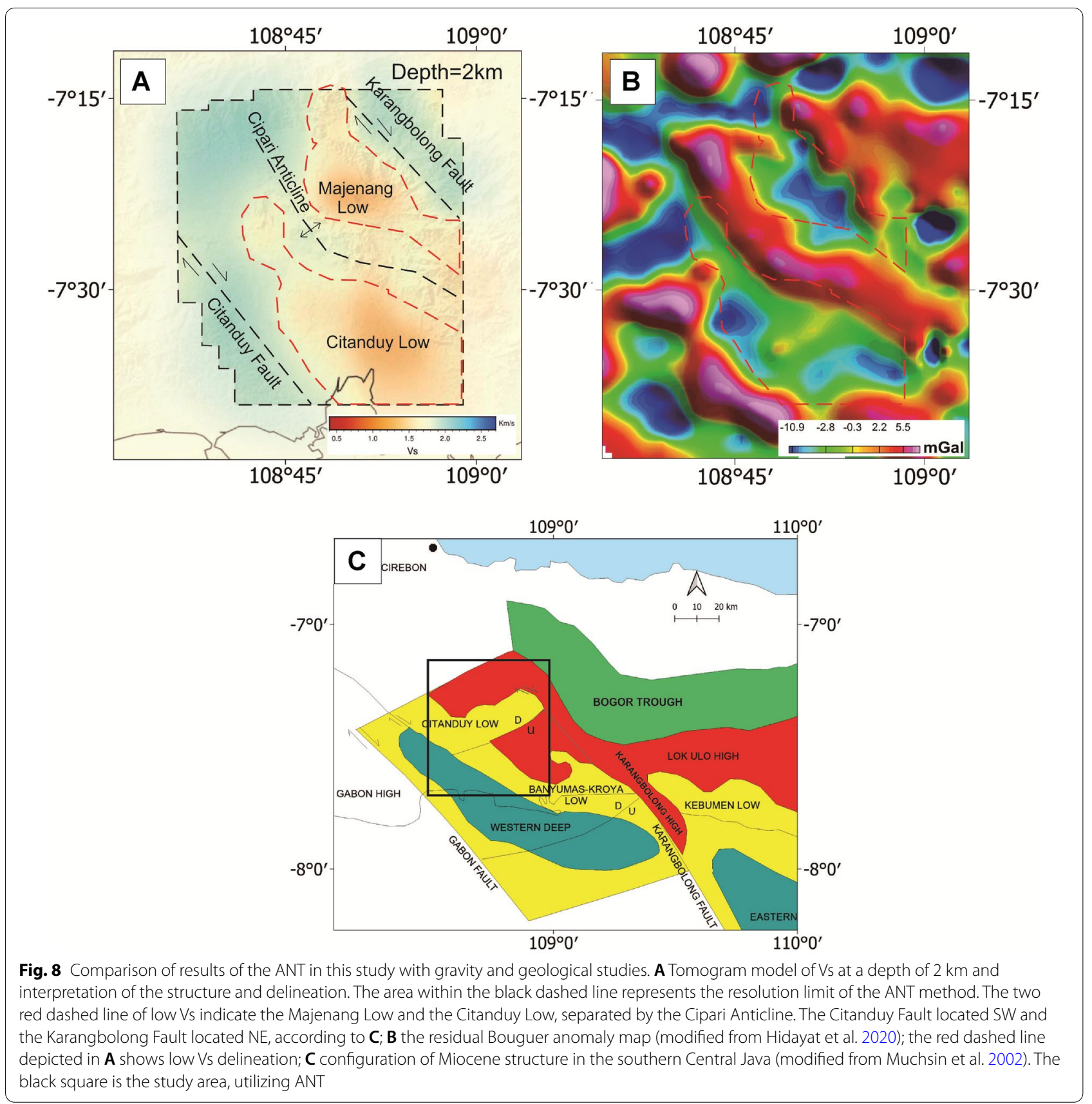

were interpreted as the Majenang Low and the Citanduy Low, respectively.

By utilizing the facies analysis of the Jati- 1 well log data from Tampubolon et al. (2014), we found three layers of subsurface structures in the Banyumas Basin that could be seen from our result. The first layer, with a value of Vs $0.8-1.7 \mathrm{~km} / \mathrm{s}$, was estimated to be a response from rocks of the Middle Miocene-Pliocene and consisted of the Kumbang, Halang, and Tapak Formations. The second layer, with a value of Vs $1.71-2.3 \mathrm{~km} / \mathrm{s}$, was estimated to be related to rocks of the Early-Middle Miocene and consisted of the sediment of the Nusakambangan, Penanjung, and Rambatan Formations. The third layer, with a value of Vs $2.31-2.7 \mathrm{~km} / \mathrm{s}$, was estimated to consist of sedimentary rock of the Eocene and the Early OligoceneMiocene of Gabon Formation. Meanwhile, the basaltic basement of the Banyumas basin could not be identified because the Vs value obtained by our result was still lower than the reference value obtained by Christensen and Stanley (2003). However, it could be estimated that 
the thickness of the Banyumas basin in the study area was more than $8 \mathrm{~km}$. Our findings could be used as additional information for hydrocarbon exploration in the Banyumas Basin.

\section{Supplementary Information}

The online version contains supplementary material available at https://doi. org/10.1186/s40562-021-00202-x.

Additional file 1: Table S1. Facies analysis data of Jati-1 well (TampuboIon et al. 2014). Fig. S1. An overview of 1291 group velocity dispersion curves of Rayleigh wave in the $1 \mathrm{~s}-10 \mathrm{~s}$ period with a range of group velocity values of $0.4 \mathrm{~km} / \mathrm{s}-3.2 \mathrm{~km} / \mathrm{s}$. Fig. S2. The trade-off curve of the regularization damping and smoothing parameters in the $1 \mathrm{~s}$ period. A The search for damping values is varied from 5000 to 10 . A damping number of 300 is obtained. B The search for smoothing values is varied from 3000 to 5. A smoothing number of 300 is obtained. Fig. S3. Inversion of the synthetic model of group velocity with Checkerboard Resolution Test (CRT) in each period with a cell size of $\sim 6.5 \mathrm{~km} 2$, damping, and smoothing factors of 300. (A) $1 \mathrm{~s}$, (B) $2 \mathrm{~s}$, (C) $3 \mathrm{~s}$, (D) $4 \mathrm{~s}$, (E) $5 \mathrm{~s}$, (F) $6 \mathrm{~s}$, (G) $7 \mathrm{~s}$, (H) $8 \mathrm{~s},(\mathrm{I}) 9 \mathrm{~s},(\mathrm{~J}) 10 \mathrm{~s}$, (K) initial synthetic model. Checkerboard patterns of synthetic models could be relatively recovered in the period $1 \mathrm{~s}-6 \mathrm{~s}$. Fig. S4. The amount of ray path in each Rayleigh wave propagation period is extracted from the dispersion curve. The amount of ray path tends to decrease with increasing periods.

\section{Acknowledgements}

We would like to thank the Center for Geological Survey (CGS), Geological Agency, Indonesia, for the waveform data used in this study. We used the do mft program (Herrmann, 2013) at the picking process of the Empirical Green's Function (EGF) to obtain the dispersion curve. Some of the figures presented were plotted using Generic Mapping Tools (Wessel and Smith 1998).

\section{Authors' contributions}

$A S, Z Z, A D N, S R$, AP, SW, DPS contributed to the data processing, interpretation, and writing of the manuscript. AS, MM, JHS, EBL, AKP, and HH conceived the seismic survey in Banyumas basin area. All authors contributed to the preparation of the manuscript. All authors read and approved the final manuscript.

\section{Funding}

This study was supported by the Ministry of Energy and Mineral Resources, Indonesia, for its scholarship, the ITB Research Program 2019-2020, the Master's Thesis Research Program BP-PTNBH Kemristek/BRIN 2020, and World Class Research Kemristek/BRIN Program 2021-2022 awarded to ADN. The study was also partially supported by and the Center for Earthquake Science and Technology, Research Center for Disaster Mitigation, Institut Teknologi Bandung (CEST, PPMB, ITB).

\section{Availability of data and materials}

Vs data will be shared through the PSG, Geological Agency, Indonesia, website after this paper is published.

\section{Declarations}

\section{Competing interests}

We declare that we have no significant competing financial, professional or personal interests that might have influenced the performance or presentation of the work described in this manuscript.

\section{Author details}

${ }^{1}$ Graduate Program of Geophysical Engineering, Faculty of Mining and Petroleum Engineering, Institut Teknologi Bandung, Jalan Ganesa No. 10, Bandung 40132, Indonesia. ${ }^{2}$ Center for Geological Survey, Ministry of Energy and Mineral Resources, Indonesia, Geological Agency of Indonesia, Jalan Diponegoro No. 57, Bandung 40122, Indonesia. ${ }^{3}$ Global Geophysics Research
Group, Faculty of Mining and Petroleum Engineering, Institut Teknologi Bandung, Jalan Ganesa No. 10, Bandung 40132, Indonesia. ${ }^{4}$ Center for Earthquake Science and Technology, Institut Teknologi Bandung, Jalan Ganesa No. 10, Bandung 40132, Indonesia. ${ }^{5}$ Faculty of Engineering, Maranatha Christian University, Bandung 40164, Indonesia.

Received: 8 March 2021 Accepted: 3 October 2021

Published online: 18 October 2021

\section{References}

Asikin S, Handoyo A, Prastistho B, Gafoer S (1992) Peta Geologi Lembar Banyumas, Jawa, Skala 1:100.000. Pusat Penelitian dan Pengembangan Geologi, Bandung (in Indonesian)

Bensen GD, Ritzwoller MH, Barmin MP, Levshin AL, Lin F, Moschetti MP, Shapiro NM, Yang Y (2007) Processing seismic ambient noise data to obtain reliable broad-band surface wave dispersion measurements. Geophys J Int 169(3):1239-1260. https://doi.org/10.1111/j.1365-246X.2007.03374.x

Christensen NI, Stanley D (2003) 83 Seismic velocities and densities of rocks. [International Geophysics] International Handbook of Earthquake and Engineering Seismology 81B: 1587-1594. https://doi.org/10.1016/S00746142(03)80278-4

Curtis A, Gerstoft P, Sato H, Snieder R, Wapenaar K (2006) Seismic interferometry-turning noise into signal. Lead Edge 25:1082-1092. https://doi.org/10. 1190/1.2349814

Djuri M, Samodra H, Amin TC, Gafoer S (1996) Peta Geologi Lembar Purwokerto dan Tegal, Skala 1:100.000. Pusat Penelitian dan Pengembangan Geologi, Bandung (in Indonesian)

Dziewonski A, Bloch S, Landisman M (1969) A technique for the analysis of transient seismic signals. Bull Seismol Soc Am 59(1):427-444

Geologi B (2009) Peta Cekungan Sedimen Indonesia. Badan Geologi, Bandung (in Indonesian)

Hall R (2012) Late Jurassic-Cenozoic reconstructions of the Indonesian region and the Indian Ocean. Tectonophysics 570-571:1-41. https://doi.org/10. 1016/j.tecto.2012.04.021

Herrmann RB (2013) Computer programs in seismology. An evolving tool for instruction and research. Seismol Res Lett 84(6):1081-1088. https://doi. org/10.1785/0220110096

Hidayat H, Subagio S, Praromadani ZS (2020) Interpretasi struktur geologi bawah permukaan berdasarkan updating data gaya berat cekungan Banyumas, Jawa Tengah. Jurnal Geologi Dan Sumberdaya Mineral 21(3):111-118. https://doi.org/10.33332/jgsm.geologi.21.3.111-118p. (in Indonesian)

Hidayat H, Nugraha AD, Priyono A, Marjiyono M, Setiawan JH, Sahara DP, Winardhi S, Zulfakriza Z, Rosalia S, Lelono EB, Permana AK, Setiawan A (2021) Travel time tomography to delineate 3-D regional seismic velocity structure in the Banyumas Basin, Central Java, Indonesia, using dense borehole seismographic stations. Front Earth Sci 9:639271. https://doi. org/10.3389/feart.2021.639271

Jiang M, Ai Y, Zhou S, Chen YJ (2014) Distribution of the low velocity bulk in the middle-to-lower crust of the southern Tibet implications for formation of the north-south trending rift zones. Earthq Sci 27(2):149-157. https://doi. org/10.1007/s11589-014-0080-1

Kastowo, Suwarna N (1996) Peta Geologi Lembar Majenang, Jawa, Skala 1:100.000 Edisi ke-2. Pusat Penelitian dan Pengembangan Geologi, Bandung (in Indonesian)

Kennett BLN, Sambridge MS, Williamson PR (1988) Subspace methods for large scale inverse problems involving multiple parameter classes. Geophys J 94(2):237-247. https://doi.org/10.1111/j.1365-246x.1988.tb05898.x

Laske G, Masters G, Ma Z, Pasyanos M (2013) Update on CRUST1.0_A 1-degree global model of Earth's crust. Geophys Res Abstracts 15:2658

Liu C, Yao H (2017) Surface wave tomography with spatially varying smoothing based on continuous model regionalization. Pure Appl Geophys 174(3):937-953. https://doi.org/10.1007/s00024-016-1434-5

Liu Z, Huang J, Yao H (2016) Anisotropic Rayleigh wave tomography of Northeast China using ambient seismic noise. Phys Earth Planet Inter 256:37-48. https://doi.org/10.1016/j.pepi.2016.05.001 
Luo Y, Yang Y, Xu Y, Xu H, Zhao K, Wang K (2015) On the limitations of interstation distances in ambient noise tomography. Geophys J Int 201 (2):652661. https://doi.org/10.1093/gji/ggv043

Martha AA, Cummins P, Saygin E, Widiyantoro S, Masturyono, (2017) Imaging of upper crustal structure beneath East Java-Bali, Indonesia with ambient noise tomography. Geosci Lett 4(14):1-12. https://doi.org/10.1186/ s40562-017-0080-9

Moody JD, Hill MJ (1956) Wrench-fault tectonics. GSA. Bulletin 67(9):12071246. https://doi.org/10.1130/0016-7606(1956)67[1207:WT]2.0.CO;2

Muchsin N, Ryacudu R, Kunto TW, Budiyani S, Yulianto B, Wiyanto B, Nurjayadi A, Raharjo K, Riandra F (2002) Miocene hydrocarbon system of the Southern Central Java region. In: Proceeding of 31st Annual Convention of Indonesian Association of Geologists

Nicolson H, Curtis A, Baptie B, Galetti E (2012) Seismic interferometry and ambient noise tomography in the British Isles. Proc Geol Assoc 123(1):74-86. https://doi.org/10.1016/j.pgeola.2011.04.002

Noeradi D, Subroto EA, Wahono HE, Hermanto E, Zaim Y (2006) Basin evolution and hydrocarbon potential of Majalengka-Bumiayu transpression basin, Java Island, Indonesia. In: AAPG International Conference and Exhibition, Perth, West Australia

Paul A, Campilo M, Margerin L, Larose E, Derode A (2005) Empirical synthesis of time-asymmetrical Green functions from the correlation of coda waves. J Geophys Res 110(B8):B08302. https://doi.org/10.1029/2004J B003521

Porritt RW, Miller MS, O'Driscoll LJ, Harris CW, Roosmawati N, da Costa LT (2016) Continent-arc Collision in the Banda Arc imaged by ambient noise tomography. Earth Planet Sci Lett 449:246-258. https://doi.org/ 10.1016/j.epsl.2016.06.011

Pranata B, Yudistira T, Widiyantoro S, Brahmantyo B, Cummins PR, Saygin E, Zulfakriza Z, Rosalia S, Cipta A (2020) Shear wave velocity structure beneath Bandung basin, West Java, Indonesia from ambient noise tomography. Geophys J Int 220(2):1045-1054. https://doi.org/10.1093/ gji/ggz493

Purwasatriya EB, Surjono SS, Amijaya DH (2019) Sejarah Geologi Pembentukan Cekungan Banyumas Serta Implikasinya Terhadap Sistem Minyak dan Gas Bumi. Jurnal Ilmiah Dinamika Rekayasa. 15(1):25-34. https://doi.org/10. 20884/1.dr.2019.15.1.242

Rawlinson N (2005) FMST Fast marching surface tomography package. Research School of Earth Science, Australian National University, Canberra

Rawlinson N, Sambridge M (2005) The fast marching method. An effective tool for tomographic imaging and tracking multiple phases in complex layered media. Explor Geophys 36(4):341-350. https://doi.org/10.1071/ EG05341

Ritzwoller MH, Lin FC, Shen W (2011) Ambient noise tomography with a large seismic array. CR Geosci 343:558-570. https://doi.org/10.1016/j.crte.2011. 03.007

Rosalia S, Widiyantoro S, Cummins PR, Yudistira T, Nugraha AD, Zulfakriza Z, Setiawan A (2021) Upper crustal shear-wave velocity structure beneath Western Java, Indonesia from seismic ambient noise tomography. Geosci Lett. https://doi.org/10.21203/rs.3.rs-591913/v1 (Under Review)

Rosalia S, Widiyantoro S, Nugraha AD, Suspendi P (2019) Double-difference tomography of $\mathrm{P}$ - and S-wave velocity structure beneath the western part of Java, Indonesia. Earthq Sci 32:12-25. https://doi.org/10.29382/ eqs-2019-0012-2

Sambridge M (1999a) Geophysical inversion with a neighborhood algorithm I. Searching a parameter space. Geophys J Int 138:479-494. https://doi.org/ 10.1046/j.1365-246x.1999.00876.x

Sambridge M (1999b) Geophysical inversion with a neighborhood algorithm II. Appraising the ensemble. Geophys J Int 138:727-746. https://doi.org/ 10.1046/j.1365-246x.1999.00900.x

Sarjan AFN, Zulfakriza Z, Nugraha AD, Rosalia S, Wei S, Widiyantoro S, Cummins PR, Muzli M, Sahara DP, Puspito NT, Priyono A, Afif H (2021) Delineation of upper crustal structure beneath the Island of Lombok, Indonesia, using ambient seismic noise tomography. Front Earth Sci 9:560428. https://doi. org/10.3389/feart.2021.560428

Satyana AH (2007) Central Java, Indonesia - A "Terra Incognita" in petroleum exploration: new consideration on the tectonic evolution and petroleum implications. In: Proceedings of Indonesian Petroleum Association, ThirtyFirst Annual Convention and Exhibition
Saygin E, Kennett BLN (2010) Ambient seismic noise tomography of Australian continent. Tectonophysics 481:116-125. https://doi.org/10.1016/j.tecto. 2008.11.013

Saygin E, Cummins PR, Cipta A, Hawkins R, Pandhu R, Murjaya J, Masturyono, Irsyam M, Widiyantoro S, Kennett BLN (2016) Imaging architecture of the Jakarta Basin, Indonesia with transdimensional inversion of seismic noise. Geophys J Int 204(2):918-931. https://doi.org/10.1093/gji/ggv466

Setiawan R (2019) Sistem hidrokarbon pada tatanan vulkanik. Konsep dan studi kasus. Publikasi khusus eksplorasi hidrokarbon di sistem vulkanik. Pusat Survei Geologi, Badan Geologi, Bandung (in Indonesian)

Setiawan R, Patriani EY, Yurnaldi D, Asmoro P, Sukapti S (2018) Stratigrafi Cekungan Banyumas, unpublished reports. Pusat Survei Geologi, Badan Geologi, Bandung (in Indonesian)

SimandjuntakTO, Surono (1992) Peta Geologi Lembar Pangandaran, Jawa, Skala 1:100.000. Pusat Penelitian dan Pengembangan Geologi, Bandung, Indonesia (in Indonesian)

Simandjuntak TO, Barber AJ (1996) Contrasting tectonic styles in the Neogene orogenic belts of Indonesia. Geologic Soc London, Special Publications 106(1):185-201. https://doi.org/10.1144/GSL.SP.1996.106.01.12

Simons WJF, Socquet A, Vigny C, Ambrosius BAC, Abu SH, Promthong C, Subarya C, Sarsito DA, Mathussen S, Morgan P, Spakman W (2007) A decade of GPS in Southeast Asia: resolving Sundaland motion and boundaries. J Geophys Res 112(B6):B06420. https://doi.org/10.1029/2005JB003868

Situmorang B, Siswoyo, Thajib E, Paltrinieri F (1976) Wrench Fault Tectonics and Aspects of Hydrocarbon Accumulation in Java. In: Proceedings of Indonesia Petroleum Association (IPA), Fifth Annual Convention, 2:53-66

Snieder R, Wapenaar K (2010) Imaging with ambient noise. Phys Today 63(9):44-49. https://doi.org/10.1063/1.3490500

Snieder R (2004) Extracting the Green's function from the correlation of coda waves. A derivation based on stationary phase. Physical Review 69(4):046610. https://doi.org/10.1103/PhysRevE.69.046610

Subroto EA, Noeradi D, Priyono A, Wahono HE, Hermanto E, Praptisih, Santoso K (2007) The paleogene basin with the Kendeng Zone, Central Java island, and implications to hydrocarbon prospectivity. In: Proceedings of Indonesian Petroleum Association, Thirty-first Annual Convention \& Exhibition

Subroto EA, Ibrahim A, Hermanto E, Noeradi D (2008) Contribution of Paleogene and Neogene sediments to the petroleum system in the Banyumas sub-basin, southern Central Java, Indonesia. In: AAPG International Conference and Exhibition, Cape Town, South Africa, pp 1-6

Tampubolon RA, Tampubolon A, Baskoro AS, Lagona R, Novandaru N (2014) Evolusi Stratigrafi, Analisis Fasies, dan Geokimia dari Sedimen Mio-Pliosen di Cekungan Banyumas. Proceeding of The 43th IAGI Annual Convention and Exhibition (in Indonesian)

Wapenaar K, Draganov D, Snieder R, Campman X, Verdel A (2010) Tutorial on seismic interferometry: Part 1 - Basic principles and applications. Geophysics 75(5):75A195-75A209. https://doi.org/10.1190/1.3457445

Wapenaar K, Draganov D, Robertsson J (2006) Introduction to supplement on seismic interferometry. Geophysics. 71(4):S11-SI4. https://doi.org/10. 1190/1.2352998

Wathelet M, Jongmans D, Ohrnberger M, Bonnefoy-Claudet S (2008) Array performances for ambient vibrations on a shallow structure and consequences over Vs inversion. J Seismol 12:1-19. https://doi.org/10.1007/ s10950-007-9067-X

Wessel P, Smith WHF (1998) New improved version of generic mapping tools released. Eos Transactions American Geophysical Union 79(47):579-579. https://doi.org/10.1029/98EO00426

Widianto E (2008) Penentuan Konfigurasi Struktur Batuan Dasar dan Jenis Cekungan dengan Data Gayaberat serta Implikasinya pada Target Eksplorasi Minyak dan Gas Bumi di Pulau Jawa. Disertasi Program Doktor, Institut Teknologi Bandung (in Indonesian)

Widiyantoro S, van der Hilst R (1996) Structure and evolution of the lithospheric slab beneath the Sunda Arc, Indonesia. Science 271:1566-1570. https://doi.org/10.1126/science.271.5255.1566

Wuryani SD, Yudistira T, Widiyantoro S (2019) Surface wave tomography using seismic ambient noise data for subsurface imaging beneath Bandung basin, West Java and its surrounding. IOP Conf Series: Earth and Environmental Science 318:012032. https://doi.org/10.1088/1755-1315/318/1/ 012032 
Yang Y, Ritzwoller MH (2008) Characteristics of ambient seismic noise as a source for surface wave tomography. Geochem Geophys Geosyst 9(2):1-18. https://doi.org/10.1029/2007GC001814

Yao H, Campman X, Hoop MV, Hilts RD (2009) Estimation of surface wave Green's functions from correlation of direct waves, coda waves, and ambient noise in SE Tibet. Phys Earth Planet Inter 177:1-11. https://doi.org/10. 1016/j.pepi.2009.07.002

Yudistira T, Paulssen H, Trampert J (2017) The crustal structure beneath The Netherlands derived from ambeint seismic noise. Tectonophysics. 721:361-371. https://doi.org/10.1016/j.tecto.2017.09.025

Zheng DC, Saygin E, Cummins P, Ge Z, Min Z, Cipta A, Yang R (2017) Transdimensional Bayesian seismic ambient noise tomography across SE Tibet. J Asian Earth Sci 134:86-93. https://doi.org/10.1016/j.jseaes.2016.11.011

Zulfakriza Z, Saygin E, Cummins PR, Widiyantoro S, Nugraha AD, Lühr BG, Bodin T (2014) Upper crustal structure of central Java, Indonesia, from transdimensional seismic ambient noise tomography. Geophys J Int 197(1):630-635. https://doi.org/10.1093/gji/ggu016

Zulfakriza Z, Nugraha AD, Widiyantoro S, Cummins PR, Sahara DP, Rosalia S, Priyono A, Kasbani K, Syahbana DK, Priambodo IC, Martanto M, Ardianto A, Husni YM, Lesmana A, Kusumawati D, Prabowo BS (2020) Tomographic Imaging of the Agung -Batur Volcano Complex, Bali, Indonesia, From the Ambient Seismic Noise Field. Front Earth Sci. https://doi.org/10.3389/ feart.2020.00043

\section{Publisher's Note}

Springer Nature remains neutral with regard to jurisdictional claims in published maps and institutional affiliations.

\section{Submit your manuscript to a SpringerOpen ${ }^{\circ}$ journal and benefit from:}

- Convenient online submission

- Rigorous peer review

- Open access: articles freely available online

- High visibility within the field

- Retaining the copyright to your article

Submit your next manuscript at $\boldsymbol{\nabla}$ springeropen.com 